\title{
Cashew (Anacardium occidentale) apple juice lowers mutagenicity of aflatoxin B1 in S. typhimurium TA102
}

\author{
Ana Amélia Melo Cavalcante ${ }^{1}$, Gabriel Rübensam², Bernardo Erdtmann², Martin Brendel ${ }^{2}$ \\ and João A.P. Henriques ${ }^{2,3}$ \\ ${ }^{I}$ Centro Federal de Educação Tecnológica do Piauí, Teresina, PI, Brazil. \\ ${ }^{2}$ Universidade Federal do Rio Grande do Sul, Centro de Biotecnologia e Departamento de Biofísica, \\ Porto Alegre, RS, Brazil. \\ ${ }^{3}$ Universidade de Caxias do Sul, Instituto de Biotecnologia, Caxias do Sul, RS, Brazil.
}

\begin{abstract}
Cashew (Anacardium occidentale) is a medicinal plant native to Brazil and also yields a nutritious fruit juice. Its large pulpy pseudo-fruit, referred to as the cashew apple, contains high concentrations of vitamin C, carotenoids, phenolic compounds and minerals. Natural and processed cashew apple juice (CAJ/cajuina) are amongst the most popular juices in Brazil, especially in the north-east. Both juices have antioxidant potential and suppress mutagenicity of hydrogen peroxide. In the present study we evaluated the inhibitory effects of $\mathrm{CAJ} /$ cajuina on Aflatoxin $\mathrm{B} 1\left(\mathrm{AFB}_{1}\right)$-induced mutation, using the Salmonella/microsome assay with the experimental approaches of pre-, co-

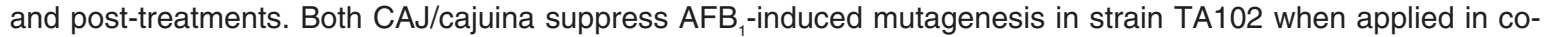
and in post-treatment. Possible mechanisms for anti-mutagenicity in co-treatment are (a) interaction with 59 enzymes, (b) metabolization to non-mutagenic compounds of $\mathrm{AFB}_{1}$ or (c) inactivation of S9 potential. Total suppression of $\mathrm{AFB}_{1}$ mutagenicity was observed in co-treatment with both CAJ and cajuina. Post-treatment anti-mutagenicity of both juices suggests a modulation of activity of error-prone DNA repair. CAJ/cajuina may be considered promising candidates for control of genotoxicity of $\mathrm{AFB}_{1}$ and may thus be considered as health foods with anti-carcinogenic potential. This promising characteristic warrants further evaluation with in vivo studies.
\end{abstract}

Key words: cashew apple juice, cajuina, anti-mutagenicity.

Received: February 13, 2004; Accepted: July 20, 2004.

\section{Introduction}

Cashew apple, the pseudofruit of the cashew tree (Anacardium occidentale), is widely consumed in the northeast of Brazil. It is regularly drunk as fresh cashew apple juice (CAJ) or as processed juice (cajuina). Studies have shown CAJ to have anti-bacterial, anti-fungal and anti-tumor activities (Kubo et al., 1993a; 1993b; Kozubek et al., 2001) as well as anti-oxidant effects (Melo Cavalcante et al., 2003) and anti-mutagenic activity (Santos et al., 2002; Melo-Cavalcante et al., 2003). As fruit juices $\mathrm{CAJ} /$ cajuina are complex mixtures, containing high concentrations of vitamin $\mathrm{C}$, various carotenoids, phenolics (quercetin, anacardic acid, tannin) and metals as biologically active compounds (Melo-Cavalcante et al., 2003). A large number of epidemiological studies have shown the

Send correspondence to Ana Amélia Melo Cavalcante. Centro Federal de Educação Tecnológica do Piauí, Praça da Liberdade 1597, Centro, 64000-040 Teresina, PI, Brasil. E-mail: ana_ameliamelo@ibest.com.br. protective effects of vegetables and fruits against cancer; this is attributed to the fact that they contain anti-mutagens as well as anti-carcinogens (Ames, 2001; Paolini and Nestle, 2003; Edenharder et al., 2003).

Chemoprevention is a promising additional method to environmental control for reducing human exposure to environmental and dietary carcinogens (Ames, 2001; De Flora et al., 2003; Park et al., 2003). Anti-mutagens and anti-carcinogens are common components in many traditional herbal remedies and dietary therapies (Zeiger, 2003; Aruoma, 2003; Surch and Ferguson, 2003). Aflatoxin B1 (AFB1) is a secondary metabolite of the fungus Aspergillus flavus (Groopman et al., 1991). Epidemiological studies have shown strong correlation between hepatocarcinoma and exposure to $\mathrm{AFB}_{1}$ (Sotomayor et al., 1999; Karekar et al., 2000). $\mathrm{AFB}_{1}$ is activated to AFB1-8,9-epoxide by the cytochrome $\mathrm{P} 450$ mono-oxygenase system. This metabolite binds covalently to DNA, RNA, and proteins (Groopman et al., 1991; Sotomayor et al., 1999). 
In our present study we report the inhibitory effects of $\mathrm{CAJ} /$ cajuina on the mutagenic activity of AFB1 in Salmonella/microsome assay, using different pre-, co- and posttreatment approaches.

\section{Materials and Methods}

\section{Preparation of juice from Anacardium occidentale}

To produce fresh CAJ, cashew fruits, obtained from the State of Piauí, Brazil, were washed and sterilized by soaking them for about $5 \mathrm{~s}$ in $70 \%$ ethanol and subsequent flaming. The cashew apples were then macerated and the juice sieved using sterile equipment. An aliquot was tested for absence of microorganisms and the juice samples were frozen at $-20{ }^{\circ} \mathrm{C}$. Cajuina was derived from CAJ by centrifugation of the macerated fruits, clarification with gelatin, filtration and thermal treatment $\left(1 \mathrm{~h}\right.$ at $\left.100{ }^{\circ} \mathrm{C}\right)$, according to the manufacturer's information (Lili Doces, Teresina, PI, Brazil). The chemical compounds identified in CAJ/cajuina (Melo Cavalcante et al., 2003) are given in Table 1.

\section{Chemicals}

Aflatoxin $\mathrm{B}_{1}\left(\mathrm{AFB}_{1}\right)$ was dissolved in dimethylsulfoxide (DMSO), both of which were purchased from Sigma (St. Louis, MO, USA).

\section{Strain}

Salmonella typhimurium strain TA102 (his G428, rfa, pKM101, PAQI), as described by Maron and Ames (1983) and Mortelmans and Zeiger (2000), was used for mutagenicity assay. The test strain was kindly supplied by Dr. B.N. Ames, University of California, Berkeley, U.S.A.

\section{Microsomal fraction}

The post-microsomal S9 fraction, prepared from livers of Sprague-Dawley rats treated with the polychlorinated biphenyl mixture Aroclor 1254, was purchased from Molecular Toxicology Inc. (Maltox ${ }^{\mathrm{TM}}$, Annapolis, Maryland, USA). The S9 metabolic activation mixture was prepared according to Maron and Ames (1983) and Mortelmans and Zeiger (2000).

\section{Anti-mutagenicity analysis}

Anti-mutagenicity of $\mathrm{CAJ} /$ cajuina against AFB1 was assessed using the standard plate incorporation assay as de- scribed by Maron and Ames (1983) and Mortelmans and Zeiger (2000), with the methodological variations described by Melo-Cavalcante et al. (2003). An overnight culture of TA102 was washed with $5 \mathrm{~mL}$ of $0.2 \mathrm{M}$ phosphate buffered saline (PBS, $\mathrm{pH}$ 7.4). The dose of AFB1 was $10 \mu \mathrm{L} /$ plate, a concentration that does not show toxicity when mixed with juices, while the doses of CAJ $(10,25$ and $50 \mu \mathrm{L} /$ plate $)$ and cajuina $(100,500$ and $2000 \mu \mathrm{L} /$ plate $)$ were selected in preliminary dose range-finding assays. The final criterion to select juice doses was their non-toxicity. We used the following controls: a) for AFB1; $\mathrm{H}_{2} \mathrm{O}+\mathrm{AFB} 1+$ bacteria + S9mix; b) for juice; $\mathrm{H}_{2} \mathrm{O}+$ juice + bacteria \pm S9mix; c) for S9mix; juice + bacteria + AFB1, with omission of S9 fractions and d) for bacteria; $\mathrm{H}_{2} \mathrm{O}+$ bacteria + $\mathrm{S} 9$ mix. Incubation was at $37{ }^{\circ} \mathrm{C}$ with continuous gentle shaking, followed by centrifugation at 3,000 rpm for 20 min (RT6000, Sorvall Instruments, DUPONT, USA). The anti-mutagenic evaluation was done by the following treatments: pre- (juice + bacteria in fresh nutrient broth (4 h), wash bacteria and add AFB1 + S9mix (20 min), wash bacteria and plate), co- (A- Bacteria + juice and AFB1 + S9mix (20 min), wash bacteria and plate. B- Juice + AFB1 $(20 \mathrm{~min})+\mathrm{S} 9 \mathrm{mix}(20 \mathrm{~min})$, add to the bacteria and plate. CAFB1 + S9mix (20 min), add juice (20 min), add bacteria and plate) and post- (A- Bacteria + AFB1 + S9mix (20 min), wash bacteria, add the juice and plate. B- Bacteria + AFB1 + S9mix (20 min), wash and incubate with juice in fresh broth (30 min), wash bacteria and plate. C- Bacteria + $\mathrm{AFB} 1+\mathrm{S} 9 \mathrm{mix}$ (20 min), wash and further incubate in fresh broth (3 $0 \mathrm{~min})$, add juice and plate). Each sample was assayed in triplicate and data are presented as means \pm SD of two independent assays. Anti-mutagenicity for each dose of $\mathrm{CAJ} /$ cajuina against AFB1 was calculated according to Melo-Cavalcante et al. (2003) as follows: percentage of inhibition $(\mathrm{I} \%)=[1-(\mathrm{B} / \mathrm{A})] \times 100$, where A represents the number of revertants/plate containing AFB1 and B represents the number of revertants/plate containing AFB1 and juices. The number of spontaneous revertants was subtracted from all plate counts. The anti-mutagenic effect of $\mathrm{CAJ} /$ cajuina, at non-toxic doses, was given as $\mathrm{ID}_{50}$, the dose causing a $50 \%$ reduction of mutagenicity in the test system. Toxicity is indicated when a decrease $>70 \%$ in the number of his + revertant colonies on plate with juice and $\mathrm{AFB}_{1}$ in relation to the number of spontaneous revertants is observed, as well as in the absence of background lawn

Table 1 - Chemical components of CAJ and of cajuina.

\begin{tabular}{lccccc}
\hline Juices $^{\mathrm{a}}$ & $\begin{array}{c}\text { Total carotenoids } \\
\text { mean } \pm \mathrm{SD}^{\mathrm{b}}\end{array}$ & $\begin{array}{c}\text { Total phenols } \\
\text { mean } \pm \mathrm{SD}\end{array}$ & $\begin{array}{c}\text { Condensed tannin } \\
\text { mean } \pm \mathrm{SD}\end{array}$ & $\begin{array}{c}\text { Quercetin } \\
\text { mean } \pm \mathrm{SD}\end{array}$ & $\begin{array}{c}\text { Anacardic acid } \\
\text { mean } \pm \mathrm{SD}\end{array}$ \\
\hline CAJ & $0.32 \pm 0.0^{* *}$ & $11.9 \pm 0.3^{* *}$ & $61.1 \pm 0.5^{* *}$ & $0.23 \pm 0.03$ & $\begin{array}{c}\text { Ascorbic acid } \\
\text { mean } \pm \mathrm{SD}\end{array}$ \\
Cajuina & $0.01 \pm 0.0^{* *}$ & $8.6 \pm 0.4^{* *}$ & $13.0 \pm 4.0^{* *}$ & $0.28 \pm 0.03$ & $0.41 \pm 0.0^{* *}$ \\
\hline
\end{tabular}

${ }^{\mathrm{a} C}$ Concentrations expressed in $\mathrm{mg} / 100 \mathrm{~g}$. ${ }^{\mathrm{b}}$ Mean value of at least three independent experiments \pm SD (Melo- Cavalcante et al., 2003). Statistical significance, one-way ANOVA Dunnett's Multiple Comparison Test. ** $\mathrm{p}<0.01$. 
and/or complete absence of growth of pinpoint nonrevertants, according to Mortelmans and Zeiger (2000) and Melo-Cavalcante et al. (2003). Co-mutagenic activities were considered to have occurred when the number of revertants on the plates with juices and AFB1 were significantly higher than those containing $\mathrm{AFB}_{1}$ only.

\section{Statistical analysis}

Statistical significance was determined by One-Way Analysis of Variance (ANOVA) using the Statistical Package for Social Science (SPSS, Chicago, 1993). Dunnett's test was used to determine whether the means of the treatments differed significantly from the positive mutagenic control. The mean difference is significant at the level of $0.01(* *)$.

\section{Results and Discussion}

In preliminary studies using $S$. typhimurium strain TA102 we ascertained that neither CAJ nor cajuina, at a dose of $100 \mu \mathrm{L} /$ plate, were non-mutagenic either with or without metabolic activation (Melo-Cavalcante et al., 2003). As shown in Table 2, AFB1-induced mutagenesis was suppressed by $\mathrm{CAJ} /$ cajuina. Protective effects against AFB1-induced mutagenesis have already been described for juices of apricots, oranges, Brussels sprouts, carrots, yellow/red peppers, tomatoes (Rauscher et al., 1998) and doesang (Korean fermented soypaste) extracts (Park et al., 2003).

In pre-treatment, $\mathrm{CAJ}$ increased the mutagenicity of AFB1, suggesting a co-mutagenic effect. However, cajuina did not show any statistically significance for comutagenicity, but had a significant indication of toxicity at $2000 \mu \mathrm{L} /$ plate. The lack of anti-mutagenic effect in pretreatments with both juices (Table 2) could be attributed to the loss of anti-mutagenic substances of $\mathrm{CAJ} /$ cajuina during washing of the juice-treated bacteria with phosphate buffer $(\mathrm{pH} 7.4)$ and/or to the alteration of $\mathrm{pH}$ due the auto-oxidation of polyphenols that occurs mainly at $\mathrm{pH}$ values above neutrality (Rueff et al., 1989). This could cause

Table 2 - Anti-mutagenic activity of CAJ/cajuina against $\mathrm{AFB}_{1}$-induced mutagenesis in TA102 with metabolic activation.

\begin{tabular}{|c|c|c|c|c|c|c|}
\hline Procedure & $\operatorname{Dose}^{\mathrm{a}}$ & $\begin{array}{c}\text { CAJ His+ } \\
\text { revertants/plate }\end{array}$ & Inhibition $\%{ }^{\mathrm{d}}$ & $\operatorname{Dose}^{\mathrm{b}}$ & $\begin{array}{c}\text { Cajuina his }+ \\
\text { revertants/plate }\end{array}$ & Inhibition $\%{ }^{\mathrm{d}}$ \\
\hline Positive control $^{\mathrm{e}}$ & - & $714 \pm 92$ & NT & - & $752 \pm 49$ & NT \\
\hline Spont. Revert. & - & $300 \pm 23$ & NT & 100 & $298 \pm 27$ & NT \\
\hline \multirow[t]{3}{*}{ S9 mix control } & 10 & $358 \pm 12$ & NT & 100 & $366 \pm 25$ & NT \\
\hline & 25 & $364 \pm 17$ & NT & 500 & $327 \pm 25$ & NT \\
\hline & 50 & $406 \pm 44$ & NT & 2000 & $377 \pm 17$ & NT \\
\hline \multirow[t]{3}{*}{ Pre-treatment } & 10 & $1420 \pm 125^{\mathrm{f} * *}$ & NT & 100 & $875 \pm 144$ & NT \\
\hline & 25 & $1108 \pm 29^{\mathrm{f} * *}$ & NT & 500 & $822 \pm 119$ & NT \\
\hline & 50 & $1464 \pm 130^{\mathrm{f}} * *$ & NT & 2000 & $207 \pm 17^{g * *}$ & NT \\
\hline \multirow[t]{3}{*}{ Co-treatment A } & 10 & $200 \pm 20^{\mathrm{g} * *}$ & NT & 100 & $120 \pm 27^{\mathrm{g} * *}$ & NT \\
\hline & 25 & $208 \pm 12^{\mathrm{g} * *}$ & NT & 500 & $115 \pm 10^{g} * *$ & NT \\
\hline & 50 & $203 \pm 10^{\mathrm{g} * *}$ & NT & 2000 & $102 \pm 21^{\mathrm{g} * *}$ & NT \\
\hline \multirow[t]{3}{*}{ Co-treatment B } & 10 & $668 \pm 26^{* *}$ & 11 & 100 & $336 \pm 28^{* *}$ & 92 \\
\hline & 25 & $506 \pm 53 * *$ & 50 & 500 & $478 \pm 54 * *$ & 60 \\
\hline & 50 & $406 \pm 13 * *$ & 74 & 2000 & $500 \pm 47 * *$ & 56 \\
\hline \multirow[t]{3}{*}{ Co-treatment $\mathrm{C}$} & 10 & $\mathrm{CAG}^{\mathrm{h}}$ & NT & 100 & $243 \pm 36$ & 112 \\
\hline & 25 & $322 \pm 35^{* *}$ & 95 & 500 & $354 \pm 34^{* *}$ & 88 \\
\hline & 50 & $346 \pm 15^{* *}$ & 89 & 2000 & $344 \pm 22 * *$ & 90 \\
\hline \multirow[t]{3}{*}{ Post-treatment A } & 10 & $342 \pm 44 * *$ & 90 & 100 & $154 \pm 24^{\mathrm{g} * *}$ & NT \\
\hline & 25 & $341 \pm 22^{* *}$ & 90 & 500 & $258 \pm 35 * *$ & 108 \\
\hline & 50 & $\mathrm{CAG}^{\mathrm{h}}$ & NT & 2000 & $394 \pm 9 * *$ & 79 \\
\hline \multirow[t]{3}{*}{ Post-treatment B } & 10 & $172 \pm 8^{g * *}$ & NT & 100 & $143 \pm 25^{\mathrm{g}}$ & NT \\
\hline & 25 & $350 \pm 18^{* *}$ & 88 & 500 & $180 \pm 2^{\mathrm{f} * *}$ & NT \\
\hline & 50 & $330 \pm 12 * *$ & 93 & 2000 & $411 \pm 78^{* *}$ & 75 \\
\hline \multirow[t]{3}{*}{ Post-treatment C } & 10 & $218 \pm 20 * *$ & 119 & 100 & $238 \pm 8 * *$ & 113 \\
\hline & 25 & $306 \pm 30 * *$ & 99 & 500 & $343 \pm 34^{* *}$ & 90 \\
\hline & 50 & $351 \pm 21 * *$ & 88 & 2000 & $377 \pm 26^{* *}$ & 83 \\
\hline
\end{tabular}

Each experiment was repeated 2 times. ${ }^{\mathrm{a}}$ Dose of CAJ in $\mu \mathrm{L} /$ plate. ${ }^{\mathrm{b}}$ Dose of cajuina in $\mu \mathrm{L} / \mathrm{plate}^{\mathrm{c}}{ }^{\mathrm{M}}$ Mean of three plates. After $48 \mathrm{~h}$ of incubation the number of revertants was counted and percentage of inhibition was calculated according to Melo-Cavalcante et al. (2003). I\% = [1-(B/A)] X 100, where A represents plates containing $\mathrm{AFB}_{1}$ and $\mathrm{B}$ represents the plate containing $\mathrm{AFB}_{1}$ and juice. ${ }^{\mathrm{d}}$ Percentage of inhibition. $\mathrm{I} \% \geq 50 \%$ was considered to show antimutagenicity. ${ }^{\mathrm{e}} \mathrm{Plates}$ containing only $\mathrm{AFB}_{1}(10 \mu \mathrm{L} / \mathrm{plate}){ }_{.}^{\mathrm{f}} \mathrm{Co}$-mutagenic activities were considered to have occurred when the number of revertants

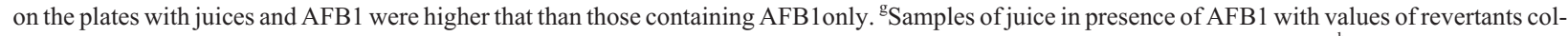
onies $>70 \%$ as compared with spontaneous revertants are considered indicative of toxicity (Mortelmans and Zeiger, 2000). ${ }^{\mathrm{h}}$ Complete absence of growth. NT (inhibition not detected). Statistical significance, one-way ANOVA followed by Dunnett's Multiple Comparison Test. ** $\mathrm{p} \leq 0.01$. 
destruction of anti-mutagenic substances in $\mathrm{CAJ} /$ cajuina, e.g. condensed tannins, quercetin and other phenolic compounds (Melo-Cavalcante et al., 2003).

However, many known anti-mutagenic chemicals of juices may also act as co-mutagens, e.g. vanillin and tannic acid. In many cases polyphenols are anti-mutagenic, depending on whether they are present before, during or after exposure to the relevant mutagen (Ferguson, 2001; Surch and Ferguson, 2003; Zeiger, 2003).

When $\mathrm{CAJ} /$ cajuina and strain TA102 were incubated with $\mathrm{AFB}_{1}$ for $20 \mathrm{~min}$ at $37^{\circ} \mathrm{C}$ with washing (co-treatment A), we observed a decrease in the number of $\mathrm{his}^{+}$ revertants/plate below the number of spontaneous mutants of the negative control for both juices, indicating the toxic effects of this treatment (Table 2). However, CAJ/cajuina in preliminary tests did not indicate toxicity at the dose used and neither was this observed for the dose of $\mathrm{AFB}_{1}$. Cashew apple juice has been shown to be cytotoxic and a potent anti-bacterial agent due the presence of anacardic acid (Kubo et al., 1993b) and resorcinolic acid (Kozubek et al., 2001). This could explain the toxicity observed in cotreatment A caused by the adverse effects of chemopreventive agents (Lee and Park, 2003). Although the toxicological effect of anacardic acid and resorcinolic acid has been investigated, the mechanisms of cytotoxic action are not yet clear.

Is known that under certain experimental conditions, many anti-oxidants can induce adverse effects, depending on their redox potential; accepting or donating electrons may render them either protective or toxic (De Flora, 1998; De Flora et al., 2001). One proposed mechanism of action for the toxicity of anacardic acid and resorcinolic acid is their strong interaction with biological membranes. This interaction may be responsible for their anti-bacterial, fungicidic and cytotoxic activity (Kozubek et al., 2001).

However, when $\mathrm{CAJ} /$ cajuina were co-incubated with $\mathrm{AFB}_{1}$ for $20 \mathrm{~min}$ at $37^{\circ} \mathrm{C}$ without washing before adding strain TA102 and plating (co-treatment B), anti-mutagenic activity was observed (Tables 2 and 3 ). Therefore, inhibition or competition for $\mathrm{S} 9$ enzymes seems to be the main anti-mutagenic mechanism of $\mathrm{CAJ} /$ cajuina, as already observed in studies on the anti-mutagenesis of Phyllanthus orbicularis extracts against aromatic amines (Ferrer et al., 2001).

One possible mechanism of anti-mutagenesis is juice- $\mathrm{AFB}_{1}$ metabolite interaction. This was suggested by the results of adding juices and strain TA102 and plating after co-incubation of $\mathrm{AFB}_{1}$ with $\mathrm{S} 9 \mathrm{mix}$ for $20 \mathrm{~min}$ at $37^{\circ} \mathrm{C}$ (co-treatment $\mathrm{C}$ ). A high anti-mutagenic effect was found, with about $95 \%$ inhibition of $\mathrm{AFB}_{1}$-induced mutagenesis (Table 2). This suggests a possible anti-mutagenic mechanism of $\mathrm{CAJ} /$ cajuina whose function would be to interact with the mutagenic metabolites of $\mathrm{AFB}_{\mathrm{I}}$ and transform them to non-mutagenic compounds. This anti-mutagenicity could be attributed to a large number of natural juice compounds (Table 1 and Table 3), i.e. carotenoids, phenols (quercetin and tannin), anacardic acid and ascorbic acid, all with anti-oxidant and anti-mutagenic properties (Melo-

Table 3 - Effects and possible active compounds of CAJ/cajuina against Aflatoxin $\mathrm{B}_{1}$ in Salmonella typhimurium TA102.

\begin{tabular}{|c|c|c|c|c|}
\hline Procedure & Effects of CAJ & Active compounds of CAJ & Effects of Cajuina & $\begin{array}{l}\text { Active compounds of } \\
\text { Cajuina }\end{array}$ \\
\hline Pretreatment & Co-mutagenic & $\begin{array}{l}\text { Ascorbic acid } \\
\text { Phenols } \\
\text { Condensed Tannins }\end{array}$ & Indicates toxicity & $\begin{array}{l}\text { Phenols } \\
\text { Condensed Tannins } \\
\text { Anacardic acid }\end{array}$ \\
\hline Co-treatment A & Indicates toxicity & Anacardic acid & Indicates toxicity & Anacardic acid \\
\hline Co-treatment B & Anti-mutagenic & $\begin{array}{l}\text { Carotenoids } \\
\text { Ascorbic acid } \\
\text { Phenols } \\
\text { Condensed Tannins } \\
\text { Quercetin }\end{array}$ & Anti-mutagenic & $\begin{array}{l}\text { Phenols } \\
\text { Condensed Tannins } \\
\text { Quercetin }\end{array}$ \\
\hline Co-treatment $\mathrm{C}$ & Anti-mutagenic & $\begin{array}{l}\text { Carotenoids } \\
\text { Ascorbic acid } \\
\text { Phenols } \\
\text { Condensed Tannins } \\
\text { Quercetin }\end{array}$ & Anti-mutagenic & $\begin{array}{l}\text { Phenols } \\
\text { Condensed Tannins } \\
\text { Quercetin }\end{array}$ \\
\hline Post-treatment A & $\begin{array}{l}\text { Anti-mutagenic } \\
\text { Indicates toxicity }\end{array}$ & $\begin{array}{l}\text { Phenols } \\
\text { Condensed Tannins } \\
\text { Quercetin }\end{array}$ & $\begin{array}{l}\text { Anti-mutagenic } \\
\text { Indicates toxicity }\end{array}$ & $\begin{array}{l}\text { Phenols } \\
\text { Condensed Tannins } \\
\text { Quercetin }\end{array}$ \\
\hline Post-treatment B & $\begin{array}{l}\text { Anti-mutagenic } \\
\text { Indicates toxicity }\end{array}$ & $\begin{array}{l}\text { Phenols } \\
\text { Condensed Tannins } \\
\text { Quercetin }\end{array}$ & $\begin{array}{l}\text { Anti-mutagenic } \\
\text { Indicates toxicity }\end{array}$ & $\begin{array}{l}\text { Phenols } \\
\text { Condensed Tannins } \\
\text { Quercetin }\end{array}$ \\
\hline Post-treatment $\mathrm{C}$ & Anti-mutagenic & $\begin{array}{l}\text { Phenols } \\
\text { Condensed Tannins } \\
\text { Quercetin }\end{array}$ & Anti-mutagenic & $\begin{array}{l}\text { Phenols } \\
\text { Condensed Tannins } \\
\text { Quercetin }\end{array}$ \\
\hline
\end{tabular}


Cavalcante et al., 2003). Carotenoids and vitamin C, which are widely distributed in fruits, play a role in genomic stability (Fenech, 2001) and were shown to inhibit metabolic activation of AFB1, benzo[a]pyrene and cyclophosphamide in vitro and in vivo (Odin et al., 1997; Rauscher et al., 1998). The phenolic compounds of the juices do not react covalently with AFB1; however inhibition of enzyme activation could lead to the formation of a chemical complex (Loarca-Pina et al., 1996; CardadorMatinez et al., 2002) or to the transformation of $\mathrm{AFB}_{1}$ to non-toxic products (Premalatha and Sachdanandam, 2000). Polyphenols may reduce production of the active metabolites through down-regulation of the relevant phase I enzymes, and/or may directly interfere with DNA adduct formation (Ferguson, 2001).

In addition $\mathrm{CA}$ /cajuina showed excellent anti-oxidant potential based on their capacity to scavenge free peroxyl radicals as measured in the Total Radical-trapping Antioxidant Potential (TRAP) assay that showed lowered oxidative damage-induced mutagenesis by co- and posttreatments (Melo-Cavalcante et al., 2003).

Anti-mutagenicity of various anti-oxidants, e.g. flavones and flavanols, against AFB1 has also been observed (Francis et al., 1989; Kusamram et al., 1998) and antocyanins (Tedesco et al., 2001) and galangin (Heo et al., 2001) show similar activity.

We observed some anti-mutagenic effect in posttreatment $\mathrm{A}$, for both juices, at 10 and $25 \mu \mathrm{L} /$ plate for $\mathrm{CAJ}$ and 500 and $2000 \mu \mathrm{L} /$ plate for cajuina. In post-treatments B and $\mathrm{C}, \mathrm{CAJ}$ showed high anti-mutagenic potential at 25 and $50 \mu \mathrm{L} /$ plate, inhibiting up to $99 \%$ of the mutagenicity of AFB1 (Table 2). However, cajuina in post-treatment B showed this inhibitory effect only at $2000 \mu \mathrm{L} /$ plate and in post-treatment $\mathrm{C}$ at 500 and $2000 \mu \mathrm{L} /$ plate (Table 2). This high anti-mutagenic potential at some doses of the posttreatment suggests protection by phenolic compounds, i.e. by quercetin, antocyanins and tannic acid, from error-prone DNA repair mechanisms (Melo-Cavalcante et al., 2003; Ferguson, 2001; De Flora et al., 2001).

In conclusion, the present study demonstrates that CAJ/cajuina may protect $S$. typhimurium strain TA102 against AFB1-induced DNA damage (Table 2) by various mechanisms, including the possible interaction with $\mathrm{S} 9$ enzymes and transformation of $\mathrm{AFB}_{1}$ and its mutagenic metabolites to non-mutagenic compounds. The stimulation of repair and/or reversion of DNA damage as observed in post-treatment could be another anti-mutagenic mechanism of $\mathrm{CAJ} /$ cajuina. This protection can be attributed to the presence of chemically active components in both juices (Table 3), which have already been shown to be involved in the protection of DNA (Melo-Cavalcante et al., 2003).

Our results indicate that $\mathrm{CAJ} /$ cajuina could be useful in protecting against a variety of compounds with mutagenic potential, that, once activated by the host, can produce mutagenic DNA adducts.

\section{Acknowledgements}

This work was supported by CEFET-PI (Centro Federal de Educação Tecnológica do Piaú, Brasil) and GENOTOX - Laboratório de Genotoxicidade, Centro de Biotecnologia, UFRGS. The authors are grateful to Dra. Christine Gaylarde for her review and constructive suggestions in improving the manuscript.

\section{References}

Ames BN (2001) DNA damage from micronutrient deficiencies is likely to be a major cause of cancer. Mutation Research 475:7-20

Aruoma OI (2003) Methodological considerations for characterizing potential antioxidant actions of bioactive components in plant foods. Mutation Research 523-524:9-20.

Cardador-Martinez A, Castano-Tostado E and Loarca-Pina G (2002) Antimutagenic activity of natural phenolic compounds present in the common bean (Phaseolus vulgaris) against aflatoxin B1. Food Additive Contaminant 19:62-69.

De Flora S (1998) Mechanisms of inhibition of mutagenesis and carcinogenesis. Mutation Research 402:151-158.

De Flora S, Izzotti A, D’Agostini F, Balansky RM, Noonan D and Albini A (2001) Multiple points of intervention in the prevention of cancer and other mutation-related diseases. Mutation Research 480-481:9-22.

De Flora S, D'Agostini F, Balansky R, Camoirano A, Bennicelli C, Bagnasco M, Cartiglis C, Tampa E, Longobardi MG, Lubet RA and Izzotti A (2003) Modulation of cigarette smoke-related end-points in mutagenesis and carcinogenesis. Mutation Research 523-524:237-252.

Edenharder R, Krieg H, Köttgen V and Plantt KL (2003) Inhibition of clastogenicity of benzo[a]pyrene and of its trans-7, 8 -dihydrodiol in mice in vivo by fruits, vegetables, and flavonoids. Mutation Research 537:169-180.

Fenech M (2001) Recommended dietary allowances (RDAs) for genomic stability. Mutation Research 480-481:51-54.

Ferrer M, Sánchez-Lamar A, Fuentes JL, Barbé J and Llagostera M (2001). Studies on the antimutagenesis of Phyllanthus orbicularis: Mechanisms involved against aromatic amines. Mutation Research 498:99-105.

Ferguson LR (2001) Role of plant polyphenols in genomic stability. Mutation Research 475:89-111.

Francis AR, Shetty TK and Bahattacharrya RK (1989) Modifying role of dietary factors on the mutagenicity of aflatoxin B1: In vitro effect of plant flavonoids. Mutation Research 222:393-401.

Groopman JD, Sabbioni G and Wild CP (1991) Molecular dosimetry of human aflatoxin B1 exposures. In: Groopman JD and Skipper PL (eds) Molecular Dosimetry and Human Cancer: Analytical, Epidemiological, and Social Considerations. Boca Raton, FL: CRC, pp 303-324.

Heo MY, Sohn SJ and Au WW (2001) Anti-genotoxicity of galangin as a cancer chemopreventive agent candidate. $\mathrm{Mu}-$ tation Research 488:13-150.

Karekar V, Joshi S and Shinde SL (2000) Antimutagenic profile of three antioxidants in the Ames assay and the Drosophila wing spot test. Mutation Research 468:183-184.

Kozubek A, Zarnowski R, Stasiuk M and Gubernator J (2001) Natural amphiphilic phenols as bioactive compounds. Cellular \& Molecular Biology Letters 6:351-355. 
Kubo I, Ochi M, Vieira PC and Komatsu S (1993a) Antitumor agents from the cashew (Anacardium occidentale) apple juice. Journal of Agricultural and Food Chemistry 41:10121015.

Kubo I, Muroi H and Himejima M (1993b) Struture-antibacterial activity relations of anacardic acids. Journal of Agricultural and Food Chemistry 41:1016-1019.

Kusamran WR, Tepsuwan A and Kupradinun P (1998) Antimutagenic and anticarcinogenic potential of some Thai vegetables. Mutation Research 402:247-258.

Lee SE, Campbell BC, Molyneux RJ, Hasegawa S and Lee HS (2001) Inhibitory effect of naturally occurring compounds on aflatoxin B(1) biotransformation. Journal of Agricultural and Food Chemistry 49:5171-5177.

Lee BM and Park KK (2003) Beneficial and adverse effects of chemopreventive agents. Mutation Research 523-524:265787.

Loarca-Pina G, Kuzmicky PA, Mejia EG, Kado NY and Hsich DP (1996) Antimutagenicity of ellagic acid against aflatoxin B1 in the Salmonella microsuspension assay. Mutation Research 360:5-21.

Maron DM and Ames BN (1983) Revised methods for the Salmonella mutagenicity test. Mutation Research 113:173-215.

Melo-Cavalcante AA, Rübensam G, Picada JN, Silva EG, Moreira FJC and Henriques JAP (2003) Mutagenic evaluation, antioxidant potential and antimutagenic activity against hydrogen peroxide of cashew (Anacardium occidentale) apple juice and cajuina. Environmental and Molecular Mutagenesis 41:360-369.

Mortelmans K and Zeiger E (2000) The Ames Salmonellal microsome mutagenicity assay. Mutation Research 455:2960 .

Odin G, Gopalam-Kriczky P, Su I, Ning Y and Lottlikar PD (1997) Inhibition of Aflatoxin B1 - induced initiation of hepatocarcinogenesis in the rat by green tea. Cancer Letters 112:149-154.
Park KY, Jung KO, Rhee SH and Choi YH (2003) Antimutagenic effects of doenjeng (Korean fermented soypaste) and its active compounds. Mutation Research 523-524:43-53.

Paolini M and Nestle M (2003) Pitfalls of enzyme-based molecular anticancer dietary manipulations: Food for thought. Mutation Research 543:181-189.

Premalatha B and Sachdanandam P (2000) Modulating role of Semecarpus anacardium L. nut milk extract on aflatoxin (1) biotransformation. Pharmacology Research 41:19-24.

Rauscher R, Edenharder R and Platt KL (1998) In vitro antimutagenic and in vivo anticlastogenic effects of carotenoids and solvent extracts from fruits and vegetables rich in carotenoids. Mutation Research 413:129-142.

Rueff J, Laires A, Brás A, Borba H, Chavea T, Gaspar J, Rodrigues A, Cristovão L and Monteiro M (1989) DNA damage and oxygen species, In: Lambert L. (eds), DNA Repair and their Biological Implications in Mammalian Cells. Plenum, New York, N.Y, pp 171-181.

Santos MC, Henriques JAP and Aragão BVA (2002) Atividade antimutagênica de frutas cítricas consumidas na dieta humana. Estudos de Biologia 24:27-32.

Sotomayor RE, Sahu S, Washington M, Hinton DM and Chou M (1999) Temporal patterns of DNA adduct formation and glutathione S-transferase activity in the testes of rats fed Aflatoxin $\mathrm{B}_{1}$ : Comparison with Patterns in the liver. Environmental and Molecular Mutagenesis 33:293-302.

Sureh YJ and Ferguson LR (2003) Dietary and medicinal antimutagens and anticarcinogens: Molecular mechanisms and chemopreventive potential-highlights of a symposium. Mutation Research 523-524:209-216.

Tedesco I, Russo GL, Nazzaro F, Russo M and Palumbo R (2001) Antioxidant effect of red wine anthocyanins in normal and catalase-inactive human erythrocytes. Journal of Nutritional Biochemistry 12:505-511.

Zeiger E (2003) Illusions of safety: Antimutagens can be mutagens, and anticarcinogens can be carcinogens. Mutation Research 543(3):191-194. 